\title{
Sinestesias en la notación gráfica: lenguajes visuales para la representación del sonido*
}

SYNESTHESIA IN GRAPHIC NOTATION: VISUAL LANGUAGES FOR THE REPRESENTATION OF SOUND

SINESTESIAS NA NOTAÇÃO GRÁFICA: LINGUAGENS VISUAIS PARA A REPRESENTAÇÃO DO SOM

\section{Marina Buj Corral**}

Cuadernos de Música, Artes Visuales y Artes Escénicas

/ Volumen 14 - Número 1 / Enero - Junio de 2019

/ ISSN 1794-6670 / Bogotá, D.C., Colombia / pp. 45-64

Fecha de recepción: 10 de mayo de 2018

Fecha de aceptación: 20 de octubre de 2018

Disponible en línea: 28 de diciembre de 2018

doi.org/10.11144/javeriana.mavae14-1.seln

* Artículo de investigación, resultado de la tesis doctoral Partituras gráficas y gráficos musicales circulares en el Arte Contemporáneo (1950-2010)", en la Universitat de Barcelona, España, diciembre de 2015.

* Licenciada en Bellas Artes por la Universidad de Granada, magíster en Flauta del Real Conservatorio Superior de Música de Granada y doctora en Bellas Artes por la Universidad de Barcelona. Docente de la Universitat de Girona y de la Universitat de Barcelona. ORCID: 0000-0002-5882-0744

\section{Cómo citar:}

Buj Corral, Marina. 2018. "Sinestesias en la notación gráfica: lenguajes visuales para la representación del sonido". Cuadernos de Música, Artes Visuales y Artes Escénicas 14 (1): 45-64. http://doi.org/10.11144/javeriana.mavae14-1.seln 


\section{Resumen}

Para representar los distintos fenómenos sonoros, la notación gráfica —escritura musical originada a mediados del pasado siglo - hace uso de una gran variedad de elementos del lenguaje visual. En este tipo de notación, la partitura actúa no solo como registro y motor de la experimentación musical llevada a cabo por los compositores de vanguardia, sino también como territorio de ensayos y pruebas con los diferentes lenguajes visuales. Este artículo profundiza en el conocimiento de los distintos lenguajes visuales utilizados en la notación gráfica con el fin de comprender cómo se relaciona el concepto musical de cada obra y compositor con el lenguaje visual elegido para su representación gráfica. Para ello, se ha llevado a cabo un estudio interdisciplinar de determinadas obras representativas de la notación gráfica realizada desde mediados del siglo XX hasta nuestros días, seleccionando los lenguajes visuales del cómic, el collage, la escultura, el vídeo y la película, la fotografía y el dibujo. La investigación pone de manifiesto la naturaleza sinestésica de la notación gráfica y destaca el carácter creativo de esta forma de escritura musical, generadora de nuevos procesos sonoros y artísticos, así como de sugerencias y recursos interpretativos. Este artículo se enfoca en el estudio de la notación gráfica como fenómeno sinestésico, musical y plástico. Y toma como punto de partida el lenguaje visual propio de cada partitura para, a partir de él, comprender cómo dialogan imagen y sonido en cada caso, cómo el pensamiento musical se materializa en una obra que es también plástica, y viceversa, cómo una obra plástica genera nuevos procesos sonoros.

Palabras clave: Notación gráfica; sinestesia; lenguaje visual; partitura gráfica; grafismos musicales; arte sonoro.

\section{Abstract}

To represent the different sound phenomena, graphic notation-musical writing originated in the middle of the last century - uses a great variety of visual language elements. In this type of notation, the score acts not only as a record and motor of the musical experimentation carried out by the avant-garde composers, but also as a territory of trials and tests with the different visual languages. This article delves into the knowledge of the different visual languages used in the graphic notation with the purpose of understanding how the musical concept of each work and composer is related to the visual language chosen for its graphic representation. For this, an interdisciplinary study of certain representative works of graphic notation made from the mid-20th century to the present day has been carried out, selecting the visual languages of comics, collage, sculpture, video and film, photography and drawing. The research evidences the synesthetic nature of the graphic notation and highlights the creative nature of this form of musical writing, as a generator of new sound and artistic processes, as well as interpretative suggestions and resources.
This article focuses on the study of graphic notation as a synesthetic, musical and plastic phenomenon. Additionally, it adopts as starting point the own visual language of each score in order to, based on it, understand how image and sound create a dialogue in each case, how musical thinking materializes in a work that is also plastic, and vice versa, how a plastic work generates new sound processes.

Keywords: graphic notation; synesthesia; visual language; graphic score; musical graphics; sound art.

\section{Resumo}

Para representar os diferentes fenômenos sonoros, a notação gráfica —escritura musical originada a meados do século passado —utiliza uma grande variedade de elementos da linguagem visual. Neste tipo de notação, a partitura atua não somente como registro e motor da experimentação musical realizada pelos compositores de vanguarda, mas também como território de ensaios e provas com os diferentes linguagens visuais. Este artigo aprofunda no conhecimento das diferentes linguagens visuais utilizados a notação gráfica com o fim de compreender como se relaciona o conceito musical de cada obra e compositor com a linguagem visual escolhida para sua representação gráfica. Para isso, realizou-se um estudo interdisciplinar de determinadas obras representativas da notação gráfica realizada desde meados do século XX até nossos dias, selecionando as linguagens visuais do cómic, o collage, a escultura, o vídeo e o filme, a fotografia e o desenho. A pesquisa põe como manifesto a natureza sinestésica da notação gráfica e destaca o caráter criativo desta forma de escritura mu sical, geradora de novos processos sonoros e artísticos, assim como de sugestões e recursos interpretativos. Este artigo se enfoca no estudo da notação gráfica como fenómeno sinestésico, musical e plástico. E toma como ponto de partida a linguagem visual própria de cada partitura para, a partir daí, compreender como dialogam imagem e som em cada caso, como o pensamento musical se materializa em uma obra que é também plástica, e vice-versa, como uma obra plástica gera novos processos sonoros.

Palavras-chave: notação gráfica; sinestesia; linguagem visual; partitura gráfica; grafismos musicais; arte sonora. 


\title{
EL LENGUAJE VISUAL COMO FORMA DE ESCRITURA MUSICAL
}

La historia del arte está llena de expresiones artísticas sinestésicas, entendiendo aquí la sinestesia como "metáfora en que una sensación correspondiente a un sentido se expresa por medio de otra correspondiente a otro" (Seco, Andrés y Ramos 1999, 4126). Desde la Antigüedad, las artes han dialogado entre sí, expresándose a través de elementos propios de otras artes. Este acercamiento, intercambio y unión entre las diferentes disciplinas artísticas ha dado lugar a la creación de nuevas realidades, sugerencias, evocaciones, a la intensificación de sensaciones y ampliación de recursos.

En concreto, las artes visuales y la música se han relacionado de diferentes formas artísticas a través de la historia, intensificándose esta relación durante el Romanticismo $y$, sobre todo, a partir de las primeras vanguardias del siglo $X X$, en figuras como Vasili Kandinski, Aleksandr Skriabin o Arnold Schönberg, y corrientes artísticas como el futurismo o la Bauhaus. Es en el siglo XX, tal como explica Ariza, cuando se produce realmente una apuesta por la percepción plurisensorial de la obra de arte:

\begin{abstract}
El siglo XX ha mostrado diversas actitudes por las cuales las categorías artísticas han quebrado sus rígidas estructuras permitiendo una fusión de las artes, una hibridación de las categorías y de los materiales. En ningún otro momento de la historia se produce con esta intensidad la mezcla y fusión en las artes. La presencia del sonido como un componente determinante en la obra artística es consecuencia de este proceso de hibridación y plurisensorialidad contemporánea. En este siglo la música y las artes plásticas convergen y se funden logrando un encuentro y diálogo inédito en el comportamiento musical y en las artes visuales. $(2008,11)$
\end{abstract}

En esta interacción entre las artes visuales y la música que tiene lugar durante el siglo $X X$, ocurre un fenómeno muy interesante, pues, si a principios de siglo las vanguardias artísticas - Kandinsky y sus contemporáneos- se acercan y toman como modelo la música, considerada desde el Romanticismo la más inmaterial y abstracta de las artes, a partir de la segunda mitad del siglo XX se advierte la tendencia inversa: muchos compositores empiezan a promover obras musicales en las cuales el aspecto visual de la partitura es tan importante como la música en sí misma, piezas para ser vistas tanto como escuchadas. En su ensayo Visual Sounds: On Graphic Scores, el filósofo y teórico del arte Christoph Cox explica así el cambio sucedido en la relación entre las artes plásticas y la música:

\footnotetext{
"Todo arte aspira constantemente a la condición de la música", escribió el esteta británico Walter Pater en 1888. La observación de Pater capturó el espíritu de la estética del siglo XIX, que glorificaba la música como la más etérea y trascendente de las artes. Menos de un siglo después de la declaración de Pater, sin embargo, se dio la vuelta a esta visión, cuando los compositores de vanguardia comenzaron a imaginar una música que aspiraba a la condición de la pintura. Morton Feldman, John Cage, Cornelius Cardew, Anthony Braxton y otros dedicaron sus trabajos a pintores y empezaron a concebir el aspecto visual de la composición musical -la escritura de una partitura - no solo como un medio a su fin, sino como un fin en sí. ${ }^{1}(2004,187)$
} 
Fruto de esta aspiración de la música "a la condición de la pintura", presente en el pensamiento de los compositores de la década de los cincuenta, y formando parte del proceso de hibridación artística que se da en el siglo XX y que se manifiesta en un gran número de expresiones artísticas contemporáneas, surge la notación gráfica.

El concepto de notación gráfica describe un tipo de partituras en las cuales se utilizan elementos del lenguaje visual que normalmente no forman parte del sistema convencional de notación musical. Si, como destacó Kandinsky en Punto y línea sobre el plano, la notación musical "no es más que una combinación de diferentes puntos y líneas" (1977, 104 y 105), la notación gráfica va más allá, incorporando colores, texturas, tonos, formas y demás elementos del lenguaje visual, que transforman la partitura en un objeto artístico portador de un valor estético como arte visual.

La notación gráfica comenzó a desarrollarse en un contexto -el Nueva York de las décadas de los cincuenta, sesenta y setenta - caracterizado por la proximidad e interacción entre creadores de distintas disciplinas artísticas, especialmente entre artistas plásticos y compositores. La enorme atracción que sintieron los compositores de vanguardia norteamericanos hacia las artes plásticas fue uno de los factores determinantes para el desarrollo de este tipo de notación. Estos compositores, John Cage, Morton Feldman, Earle Brown y Christian Wolff, entre otros, encontraron en las artes plásticas un modelo que les ayudó a superar los convencionalismos y el peso de la tradición musical. Como explica Von Maur (1999), estos compositores se sirvieron del lenguaje abstracto y autónomo desarrollado por los pintores en las décadas anteriores para sus propios fines. Descubrieron que podían expandir su inspiración musical en nuevas direcciones a través de signos de notación visuales que ya no estaban sujetos al pentagrama, sino definidos por el espacio: "La notación, que había servido únicamente como medio auxiliar para registrar ideas musicales para su interpretación, floreció en la independencia visual de los 'gráficos musicales'" (114-115).

Otro de los factores que intervino en el desarrollo de la notación gráfica fue la propia evolución y transformaciones del lenguaje musical durante el siglo XX. La incorporación de nuevas técnicas y materiales sonoros, así como la aparición de nuevas corrientes y formas de pensamiento musical, desembocaron en una crisis del sistema tradicional de notación a finales de la década de los cincuenta y en la creación de nuevas formas de notación musical, muchas de ellas basadas en el aspecto visual. Como indica Cox (2004),

no solo la fascinación por las artes visuales influyó en la proliferación de las partituras gráficas en las décadas de los cincuenta, sesenta y setenta, sino también las consideraciones prácticas, musicales, desempeñaron un importante papel. La aparición de la música electrónica y la cinta magnética en la década de los cincuenta exigieron nuevas técnicas de notación. ¿Cómo registrar los ruidos de la fábrica, o los barridos y garabatos de los tonos sinusoidales? En la mayoría de las ocasiones, los compositores optaron por una traducción visual directa del material sonoro. (188)

Esta crisis de la notación a finales de la década de los cincuenta dio lugar a la creación de una enorme variedad de signos y códigos semiográficos nuevos y a una gran riqueza de formas de escritura musical, fruto de las continuas búsquedas y la experimentación en la música del siglo XX. El compositor catalán Mestres (1993) ha resumido las nuevas formas de 
escritura de la música en tres grandes ejes: nuevos medios sonoros, aspecto visual y códigos de instrucciones. En cuanto a las partituras de aspecto visual, afirma que en ellas la notación se considera por ella misma como sujeto de interés y que "hay obras en que la forma gráfica de la notación es parte integrante de su propia existencia y que no pueden ser imaginadas ni compuestas de otro modo" (83). Destaca así Mestres un aspecto muy importante de estas obras, que es la relación indisoluble entre la idea musical y la imagen mediante la cual se representa esta idea. Esta estrecha correlación entre la idea musical y su representación visual en las partituras gráficas es puesta de relieve también por Hope y Vickery (2011): “Las partituras de Roman Haubenstock-Ramati, Sylvano Bussotti, George Crumb y otros comenzaron a divergir de los sistemas horizontales de la notación tradicional y a explorar la noción de una correlación más estrecha entre la idea y su representación" (4).

A su vez, en su artículo titulado "El ojo que prolonga el oído", Reih (1993) describe la notación gráfica como un género informalista y caracterizado por una amplia indeterminación de la obra musical, en el cual "por procedimientos sinestésicos se propone al intérprete cierto estímulo visual que le motiva sensaciones traducibles en sonidos". Según Reih, "esta incorporación de elementos significantes no musicales —al menos en origen-, sugiere en la propia composición situaciones y organizaciones sonoras novedosas, quizá no deducibles musicalmente" (87 y 88).

Esta sugerencia y proposición de situaciones y organizaciones novedosas que tiene lugar gracias a la relación sinestésica entre imagen y sonido a la que se refiere Reih es justa-

mente una de las contribuciones esenciales de la notación gráfica. Los grafismos musicales son, ante todo, imágenes de estimulación creativa. Tal como afirma Bosseur (2006, 193), las notaciones gráficas pretenden desorientar al intérprete y cuestionar sus reflejos de lector, conduciéndolo a una comprensión diferente de la práctica musical, en la que lo escrito no es una referencia absoluta. Es necesario, pues, que el intérprete se involucre creativamente en mayor grado que en la notación convencional. Esto nos conduce a otro aspecto fundamental de aquellas que es el cambio que tiene lugar en la relación entre compositor e intérprete, convirtiéndose este último en cocreador de la obra y la versión creada por él en una de las múltiples versiones posibles, de carácter único.

\section{LENGUAJES VISUALES EN LAS PARTITURAS GRÁFICAS}

En la partitura gráfica, la correlación entre la idea musical y su representación visual afecta, como se verá a continuación, a la elección del lenguaje visual que mejor se adecua en cada caso a las características musicales de la obra. La utilización de un determinado lenguaje visual —el cómic, el collage, la escultura, el vídeo, la fotografía o el dibujo, por citar algunos de ellos - no es casual. En la mayoría de casos, se da una estrecha correspondencia entre las características plásticas y expresivas del lenguaje visual elegido y la concepción musical de la obra. Siendo, además, la notación gráfica una expresión artística contemporánea, participa de la experimentación con los distintos lenguajes, técnicas de expresión y materiales artísticos. 


\section{PARTITURA-CÓMIC}

El lenguaje del cómic y, concretamente, sus elementos sonoros, las onomatopeyas, fueron utilizados en Stripsody (1966) por Cathy Berberian (1925-1983). La compositora y mezzosoprano estadounidense creó esta obra — dibujada por Roberto Zamarín- para explorar a través de ella su propia técnica vocal basándose en los sonidos onomatopéyicos de los cómics. En opinión de Garbuglia, Stripsody (figura 1) plantea preguntas cruciales sobre el papel desempeñado por los sonidos onomatopéyicos en el mundo silencioso de los cómics: ¿Son todos iguales? ¿Qué tipo de relación mantienen con los objetos que las producen? ¿Tenemos que llevarlas a cabo? ¿Y si es así, qué sucede cuando lo hacemos?

De hecho, él [Zamarín] opta por invertir la habitual relación que existe en las viñetas entre dibujos animados y sonidos, poniendo los primeros al servicio de los segundos. La inversión es especialmente evidente en el undécimo gráfico, en el que el autor alude al papel ocupado por la banda sonora de la película, relegando los fotogramas a una columna horizontal, al margen de la representación de sonidos. (2011, parte I)

En otras ocasiones, el lenguaje del cómic convive con partituras escritas con los signos de notación convencionales. Esto ocurre, por ejemplo, en la obra Tha-Chooom! (1998), de Sven Hermann, para solo de viola de gamba con CD y proyección, en que, junto con el pentagrama y las notas, aparecen imágenes de héroes del cómic norteamericano.

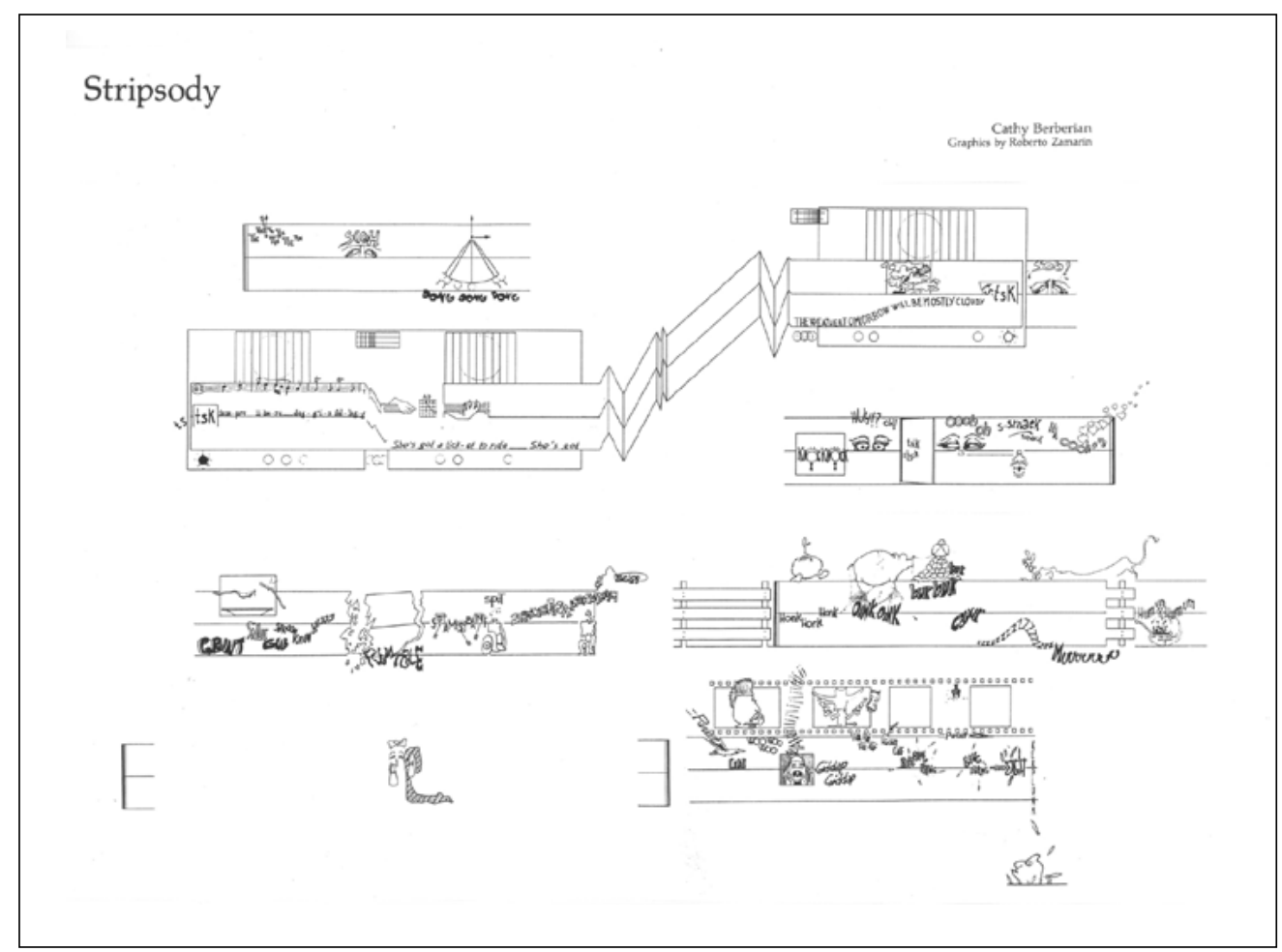

Figura 1. Extracto de Stripsody de Cathy Berberian (EP66164).

(c) Copyright 1966 por C.F. Peters Corporation, New York para todos los países del mundo. Reimpreso en nombre de los editores con permiso de Peters Edition Limited, London.

Fuente: Berberian (1966). 


\section{PARTITURA-COLLAGE}

Otras veces, las partituras musicales están realizadas a través de un collage de elementos diversos. En estos casos, la fuerza expresiva de los distintos materiales es la que sugiere nuevas propuestas sonoras. Si, como afirma Díaz $(2007,310)$, el collage propició un nuevo modo de concebir la obra plástica y abrió caminos a nuevas poéticas de carácter estético, la incorporación del collage en las partituras descubre también nuevas posibilidades musicales, basadas en la expresividad de los materiales y en la interacción entre estos con las ideas musicales de la obra. Con la incorporación del collage en las partituras musicales (uso de recortes, fragmentos de imágenes, materiales de todo tipo, diferentes texturas, etc.), la partitura musical adopta unas cualidades plásticas inusitadas. La plástica y la experimentación con los materiales irrumpen de lleno en la partitura.

Uno de los primeros ejemplos de partitura-collage lo hallamos en Notations, compendio de partituras gráficas realizado por John Cage y Alison Knowles en 1969. Se trata de Sketch for a Tragic One-Act Opera (1965), del compositor norteamericano Robert Moran. En ella vemos una cuchilla de afeitar y recortes de papeles pegados al soporte de la partitura, entre pentagramas y otros grafismos. Todos ellos están dispuestos según la tradicional organización de una partitura orquestal, en la cual las líneas de los diferentes instrumentos se presentan horizontalmente para ser leídas de manera simultánea por el director (figura 2).

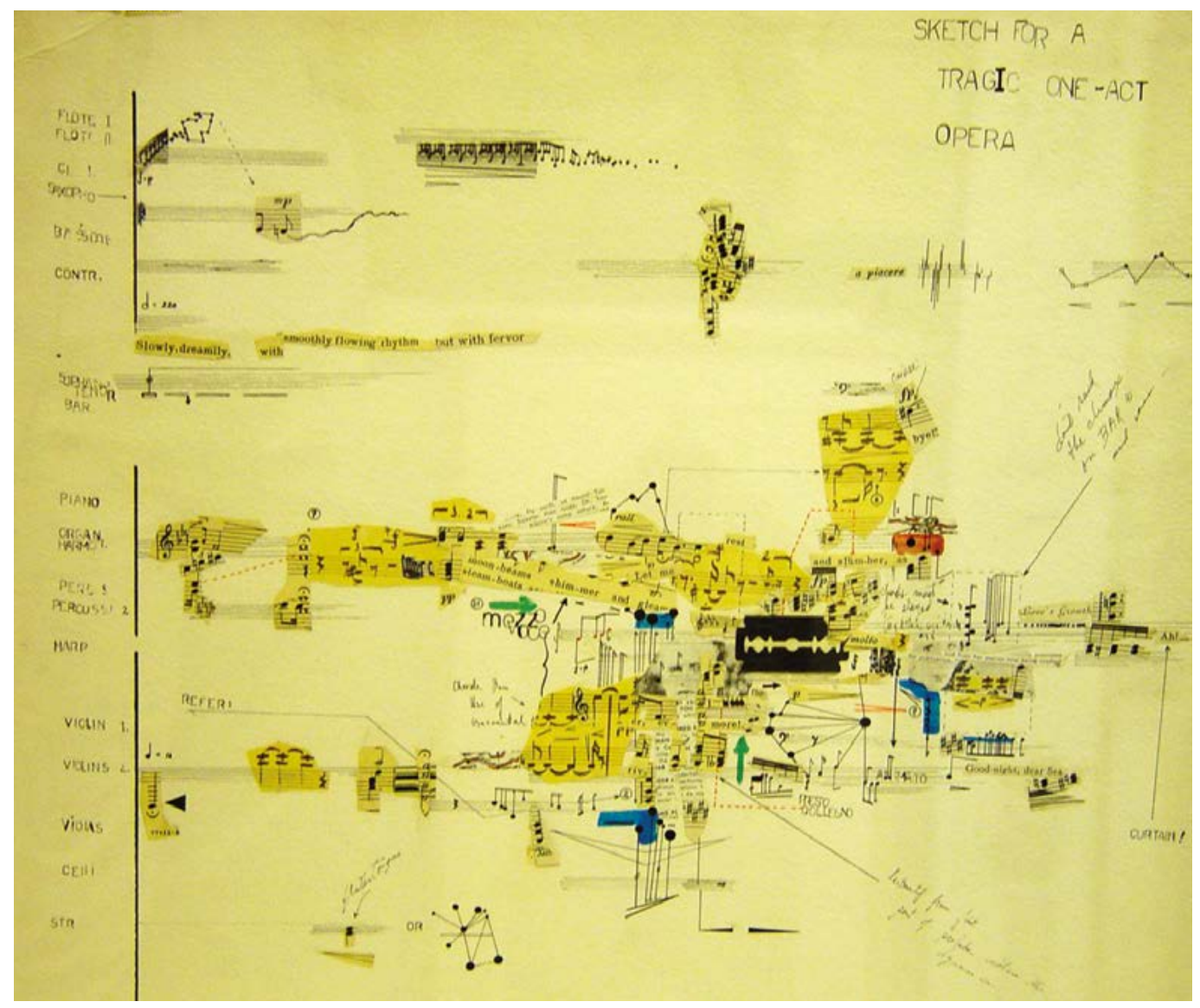

Figura 2. Sketch for a Tragic One-Act Opera.

(c) Copyright Robert Moran, reproducido con el permiso del compositor Fuente: Moran (1965) 
La técnica del collage ha sido en lo sucesivo explorada por un gran número de compositores en sus partituras. Sin embargo, uno de los casos más representativos en lo que se refiere al desarrollo de este lenguaje visual ha sido el compositor chileno-israelí León Schidlowsky (1931-). Para este autor, el uso del collage está unido a su concepción del proceso compositivo, basado en la síntesis de distintos elementos:

\begin{abstract}
El compositor explotó, a través de la notación gráfica, la posibilidad de trabajar flexiblemente en una síntesis de elementos diversos. Esto desembocó en una concepción cada vez más compleja, un arte global (Gesamtkunstwerk), donde la acción (teatro), imagen (plástica), el sonido (música), texto (literatura) son intercomunicables. (Fugellie 2012, 15)
\end{abstract}

Una de las obras gráficas más características de Schidlowsky en cuanto al desarrollo de este lenguaje es Deutschland, ein Wintermarchen (1980). Explica Fugellie $(2012,25)$ que, gráficamente, cada movimiento de la obra es un collage integrado por dibujos, neumas musicales, letras, fonemas, recortes de revista y formas abstractas. El color de la partitura intensifica el dramatismo de los distintos movimientos. La partitura-collage es también una representación del escenario en el que se interpreta la obra (figura 3).

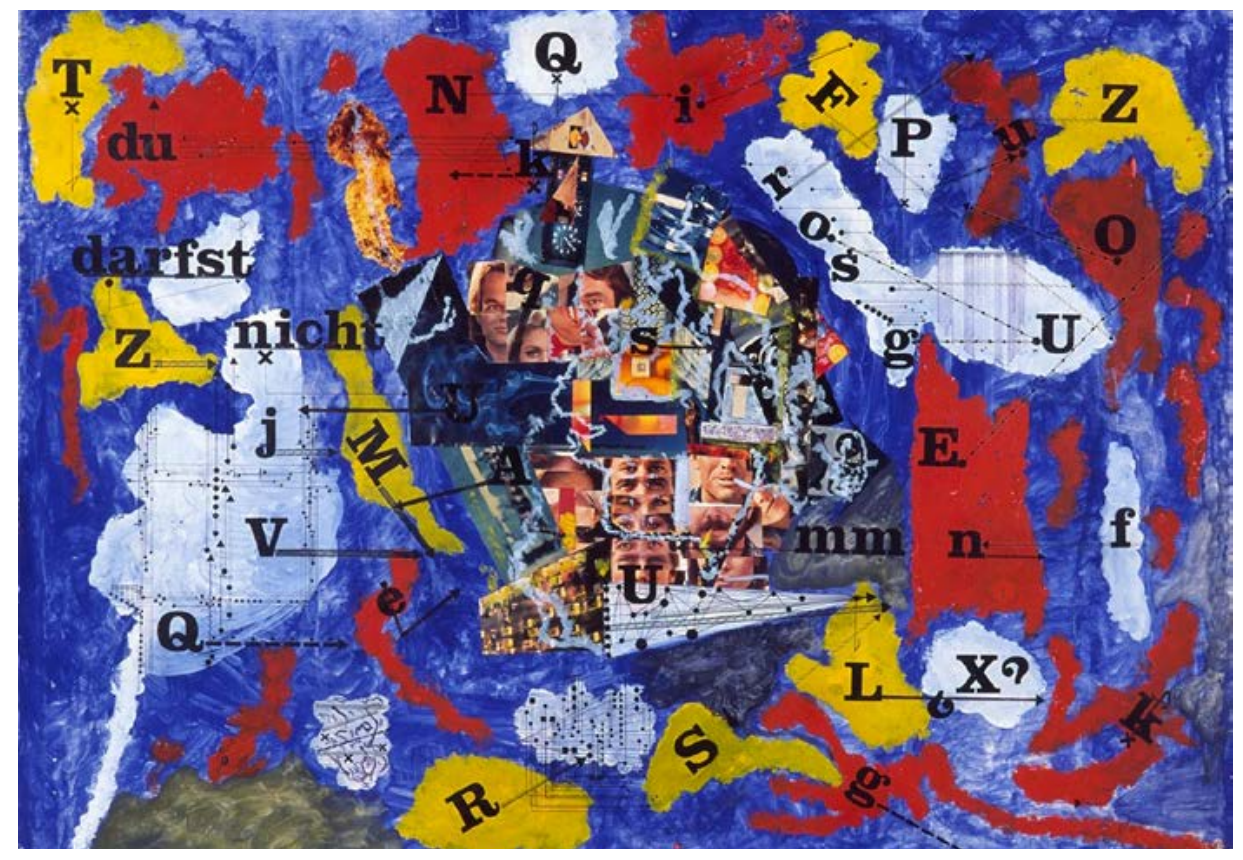

Figura 3. Deutschland, ein Wintermarchen. Parte 2.

(c) Copyright León Schidlowsky, reproducido con el permiso del compositor.

Fuente: Schidlowsky (1980).

En la actualidad, las partituras visuales siguen incorporando materiales diversos, utilizados por su fuerza expresiva. En Notations 21, antología en la que Theresa Sauer (2009) reúne ejemplos de notación gráfica realizados en los últimos años, encontramos obras como Gingko (2007), de Jon Raskin, en la que los músicos asignan una nota o sonido a cada punto escrito sobre una hoja del árbol Gingko biloba. Cada hoja de gingko constituye una serie de sonidos y la pieza central corresponde a una improvisación en grupo (Raskin 2009, 184). 


\section{LA PARTITURA-ESCULTURA}

En ocasiones, la notación gráfica incorpora la tercera dimensión, convirtiéndose en lo que podríamos llamar una partitura-escultura o partitura-objeto. Las partituras visuales de William Hellermann —artista que destaca, entre otros aspectos, por ser el creador del término "arte sonoro" - han evolucionado desde la utilización de formas abstractas hasta una concepción escultural basada en la escritura musical sobre objetos, pasando por el concepto de música visible. Hellermann (2011) explica que, tal como hicieron otros muchos compositores a principios de la década de los setenta, experimentó con la notación gráfica. Visualmente, se trataba de un tipo de notación que empleaba formas abstractas —círculos, triángulos y todo tipo de símbolos dispuestos en líneas de forma libre- que, sin embargo, reiteraban aún formas musicales antiguas. A partir del planteamiento de qué hacer con la forma musical, en 1974 comenzó una serie de obras tituladas Visible Music, cuyas partituras, a diferencia de las anteriores, estaban basadas en estructuras visuales figurativas como base para composiciones musicales abstractas.

Después de un tiempo realizando partituras gráficas, Hellermann decidió utilizar objetos tridimensionales como soporte para sus partituras musicales. Invirtiendo el proceso convencional del dibujo, que trata de capturar las tres dimensiones y pasarlas a la superficie bidimensional, Hellermann comenzó a dibujar imágenes bidimensionales (notación musical) en objetos tridimensionales. Estos objetos sugieren al intérprete múltiples posibilidades sonoras. Tal como explica Hellermann (2011), las notas son literales, pero pueden secuenciarse o transponerse para combinarse de diferentes maneras. Un ejemplo de ello es la obra (...) In Effect (1986), que se presenta en forma de tres martillos de plástico. Según el autor, eso implica la utilización de instrumentos que requieren golpear las notas, tales como la marimba, el vibráfono, las campanas, etc., así como cierto efecto de transparencia. El hecho de que la partitura-objeto esté compuesta por tres objetos con notas similares escritas en cada uno de ellos sugiere usar algún tipo de imitación canónica o de fuga en su realización (87).

Como consecuencia de experimentar un constante intercambio entre los fenómenos visivos y sonoros, Hellermann comenzó a escribir música en objetos cotidianos y esto le llevó a realizar obras sin notas musicales específicas que se incluyen como parte central de la realización musical, como sucede en Experimental Music. Estas obras hacen referencia a la música y en ellas la notación musical no está escrita con detalle, dejando la interpretación musical a la imaginación del intérprete. Otro ejemplo es Staff of Life // (1985) para sintetizador, cinta magnética y escultura. Esta obra representa un tostador anticuado que se abre a ambos lados. En ella el artista añade notas y pentagramas tradicionales a las dos piezas de pan tostado (figura 4). A Hellermann corresponde la creación del concepto de score-art (arte-partitura), descrito en una extensa carta al compositor Philip Corner.

Otro ejemplo de partitura-escultura lo encontramos en la serie Weather Scores, de la escultora Nathalie Miebach. Para su realización, Miebach traslada los datos meteorológicos de las ciudades a partituras musicales, que son posteriormente traducidas a esculturas. Estas obras presentan la doble función de registrar datos científicos -en este caso las condiciones meteorológicas de un determinado lugar y momento-y ser a la vez partituras musicales en tres dimensiones que serán interpretadas por músicos. Aunque estos tienen libertad para interpretar las esculturas, se les exige no cambiar la relación esencial de las notas, para asegurar que lo que se oye corresponde a las relaciones meteorológicas de los datos. 


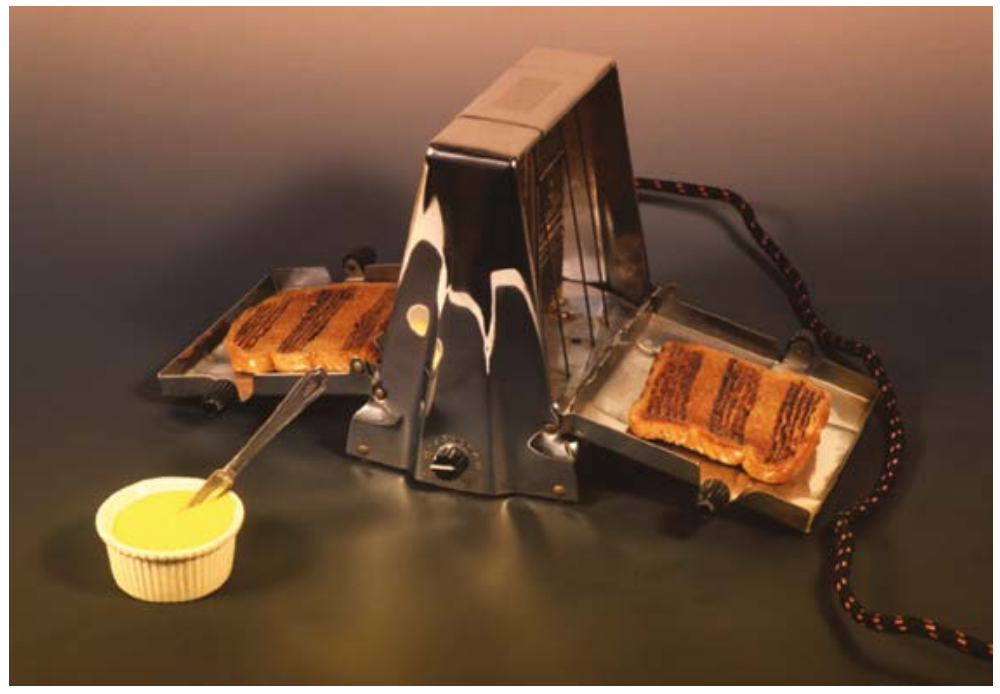

Figura 4. Staff of Life II.

Fuente: Hellerman (1985)

\section{VÍDEO-PARTITURAS Y PARTITURAS FÍLMICAS}

Dentro de las partituras gráficas que utilizan el vídeo como medio de expresión destaca la obra de Eugènia Balcells, pionera del vídeo y de la instalación en España. Entre ellas, Flight (1981), en la que "el azaroso vuelo de los pájaros detrás del pentagrama inmóvil en la pantalla sugiere las alturas de las notas que el intérprete ha de tocar mientras traduce sus sensaciones a las imágenes propias de su lenguaje musical" (Berenguer 1993, 44). "Las subidas y bajadas, el ritmo de las alas y las diferentes configuraciones son interpretados como anotaciones musicales. A pesar de la gran libertad otorgada al intérprete, la partitura visual posee un sentido del ritmo y del tempo que ofrece una pauta visual a los intérpretes" (Eugènia Balcells, comunicación personal, 14 de mayo de 2015) (figura 5).

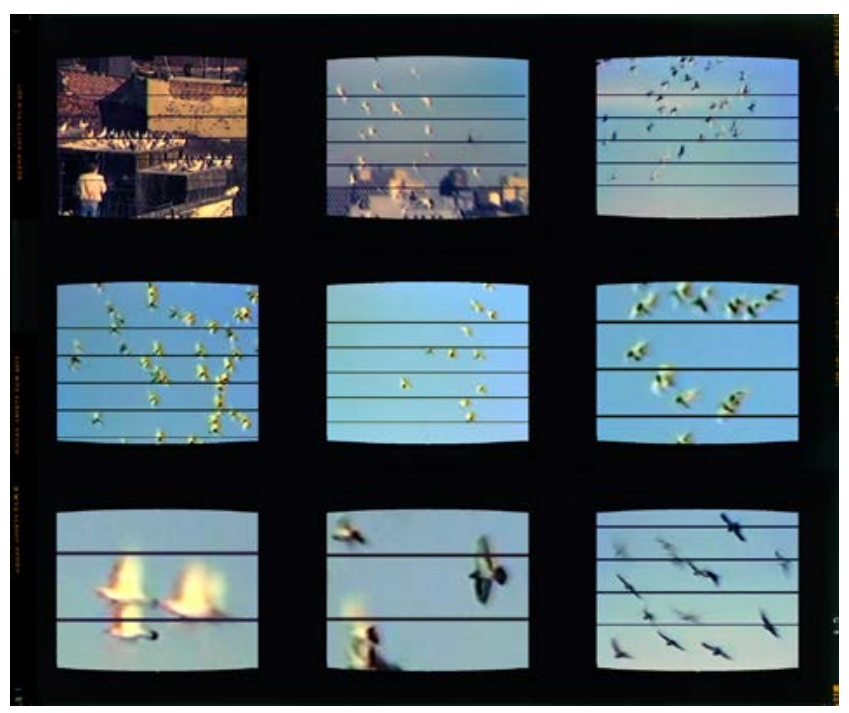

Figura 5. Flight.

(c) Copyright Eugènia Balcells, reproducido con el permiso de la artista. Fuente: Balcells (1981). 
La artista catalana cuenta con otras partituras visuales en formato de vídeo, como Water Music (1995), compuesta para dos voces a partir de imágenes de agua que se proyectan a gran tamaño para la performance o Color Fields (1984), en la que la visualización de una serie de secuencias de colores es la base para la interpretación que el músico realiza con bates de béisbol de aluminio suspendidos en cables en el espacio. En esta obra, las reverberaciones de los sonidos de metal se relacionan con los colores cambiantes de la partitura.

Asimismo, Balcells ha realizado una partitura-película, que lleva el título de Film Score (1995), y que consiste en cinco líneas rayadas en el celuloide de una película de $16 \mathrm{~mm}$. Estas se proyectan a gran tamaño sobre una pantalla y sobre el intérprete vestido de blanco. Film Score fue creada para las performances que se llevaron a cabo en el Museo Nacional Centro de Arte Reina Sofía, con la idea de crear una partitura de luz mediante el rasgado directo de toda una cinta de celuloide. Esta obra fue interpretada por Peter van Riper en el concierto Imágenes para Sonidos. La vibración de luz de la partitura actúa como estímulo y crea un sonido muy continuo y "monocorde" (Eugènia Balcells, comunicación personal, 14 de mayo de 2015) (figura 6).

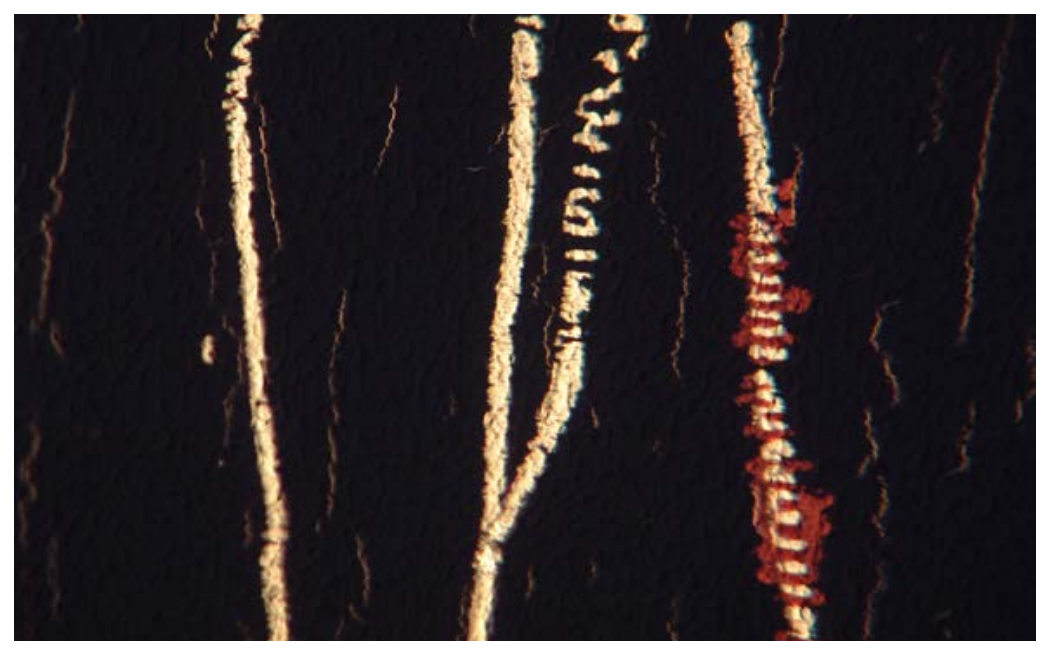

Figura 6. Film Score.

(c) Copyright Eugènia Balcells, reproducido con el permiso de la artista. Fuente: Balcells (1995).

Otros artistas han continuado trabajando con el vídeo como partitura para la interpretación musical. Es el caso de la artista y compositora establecida en Nueva York Marina Rosenfeld. Una de sus vídeo-partituras es Whitelines (2003-2010), concebida para ser leída en tiempo real tanto por los intérpretes como por el público. La obra está pensada para ser proyectada sobre una pantalla situada entre ambos. Como sucede en otras partituras visuales, esta pieza pretende acercar el acto de la lectura al público, haciendo que este forme parte del proceso. Los intérpretes que observan el vídeo traducen a sonido los cambios de dos líneas blancas que van variando su amplitud y transparencia. Estos dos parámetros visuales corresponden a distintos parámetros musicales, tales como la altura, el ritmo, la armonía, la dinámica, etc. En cada interpretación musical, se establece una determinada correspondencia entre parámetros visuales y sonoros. 


\section{PARTITURAS FOTOGRÁFICAS}

La fotografía forma, asimismo, parte de los medios utilizados por compositores y artistas para la realización de partituras visuales. El compositor y fotógrafo norteamericano Dennis Báthory-Kitsz emplea este lenguaje en algunas de sus obras. Lunar Cascade in Serial Time (2007) (figura 7) consiste en trece movimientos relacionados cada uno de ellos con un mes del año más un último movimiento titulado New Moon. Algunos de estos movimientos incorporan fotografías realizadas por el compositor, relacionadas temáticamente con cada mes del año. La imagen fotográfica se relaciona de diferentes maneras con la notación convencional: en ocasiones, posee una densidad y un color que se encuentran también en las secciones escritas en notación convencional, como sucede en la partitura del mes de mayo de la citada obra. En la partitura correspondiente al mes de junio, una rosa fotografiada sirve como base sobre la cual se superponen pentagramas circulares. En esta ocasión, el material musical se extrae directamente de ciertos elementos de la imagen, como el contorno y las gotas de agua situadas sobre la rosa. En otros casos, como en la partitura de New Moon, es la simplicidad de la imagen la que inspira los elementos musicales (Báthory-Kitsz, comunicación personal, 26 de abril de 2017).

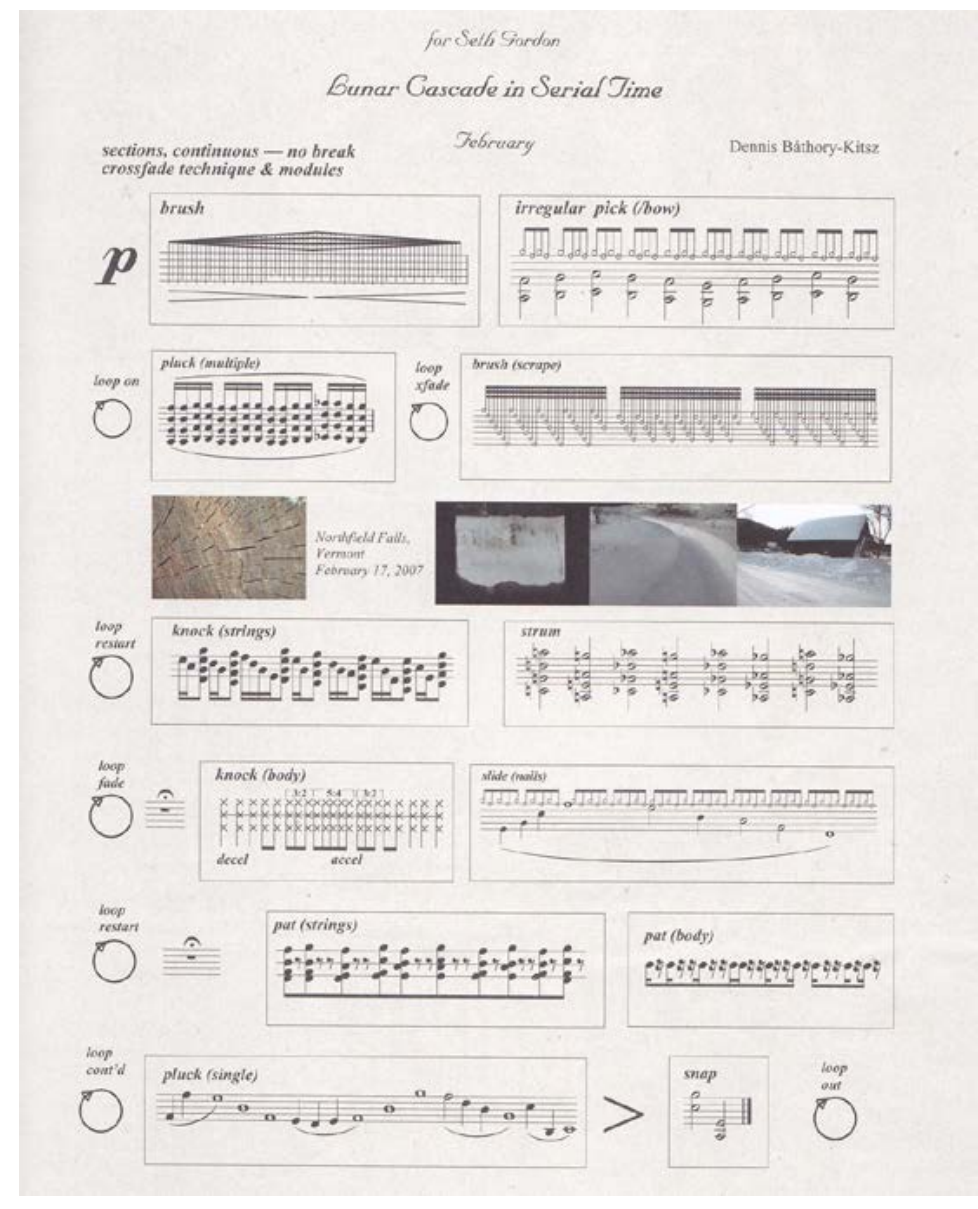

Figura 7. February: Lunar Cascade in Serial Time.

(c) Copyright Dennis Báthory-Kitsz y Westleaf Edition, reproducido con el permiso del compositor y de Westleaf Edition.

Fuente: Báthory-Kitsz (2007) 
El lenguaje fotográfico está también presente en partituras realizadas para la improvisación, como sucede en la serie Stone, Brick, Glass, Wood, Wire (1992), del compositor, guitarrista e improvisador británico Fred Frith, compuesta para cualquier número de intérpretes. Las fotografías que integran esta serie de partituras corresponden a texturas visuales creadas por diferentes objetos y materiales: muros de ladrillo, montones de piedras, hileras de ventanas de vidrio, etc. En cada una de ellas, Frith establece un cierto tipo de paralelismo entre la imagen y su interpretación, basado en la estructura de la imagen y los elementos visuales (figura 8).

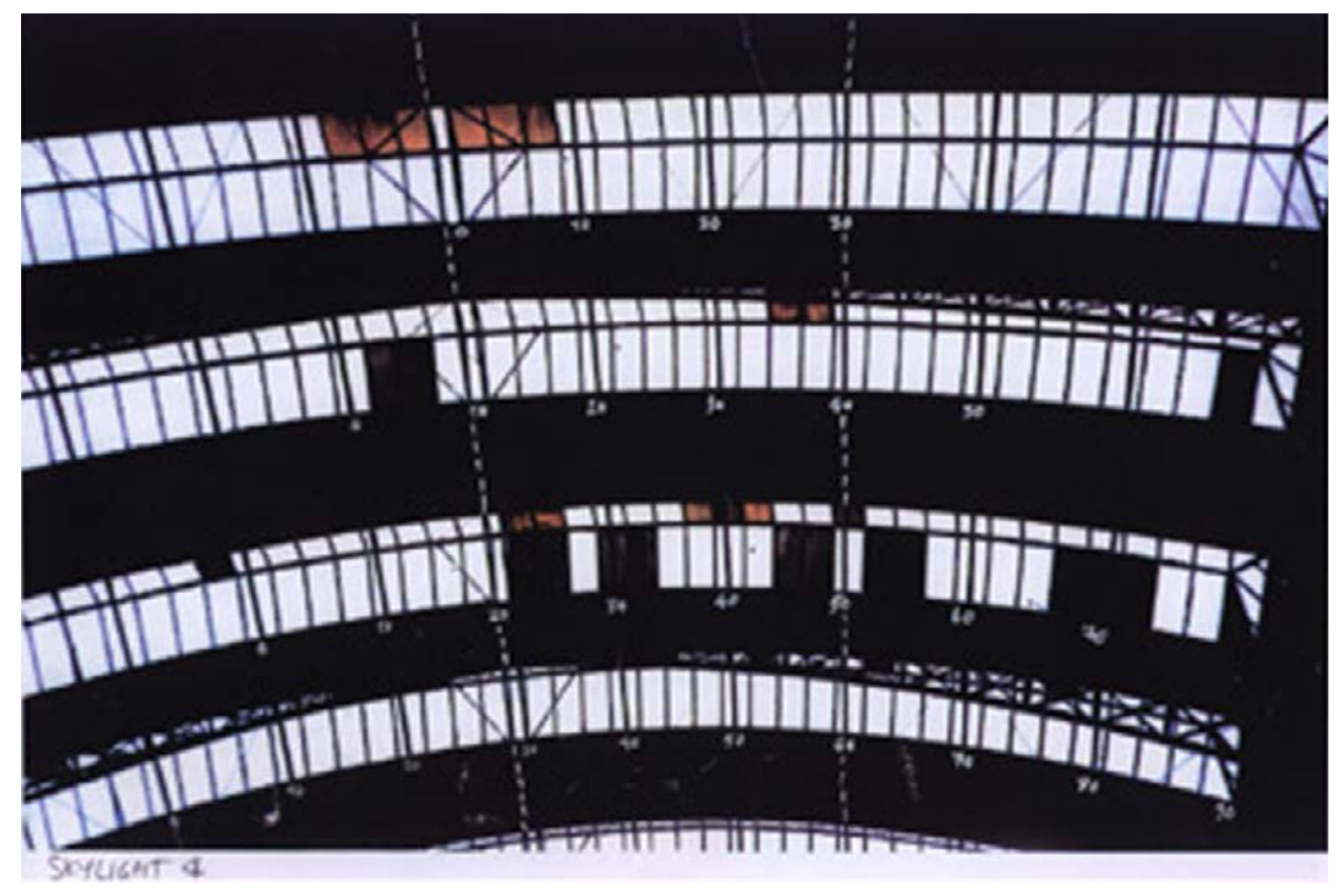

Figura 8. Skylight IV. Fuente: Frith (1999).

Por ejemplo, en Skylight IV (figura 8), la división de las tres primeras hileras de ventanas en dos partes es traducida musicalmente por Frith en tres dúos ( $A$ : tambores y arpa, B: barítono y piano, C: cajas de ritmos y clarinete bajo), mientras que la última hilera, en la que esta división no es tan marcada, es interpretada como un solo (D: trompeta). En esta obra, las líneas verticales y los bloques negros indican silencio. Frith adjudica una duración de 4 min a la obra, basada en tres dúos y un solo acumulativos y escalonados, que se van repitiendo.

En otros casos, la fotografía se utiliza en partituras de performances musicales como la obra Descripció d'un vers, del artista catalán Perejaume (figura 9), que representa un lied interpretado simultáneamente al piano en el puerto de Tarragona y a la voz en la montaña de Les Agudes, o en Auditory, de Nadia Lichtig, que plasma una instalación-performance en la que el espectador puede observar, a través de un telescopio, a una chica cantando en un puente situado a varios kilómetros del mirador. La fotografía complementa la escritura de la performance musical. 


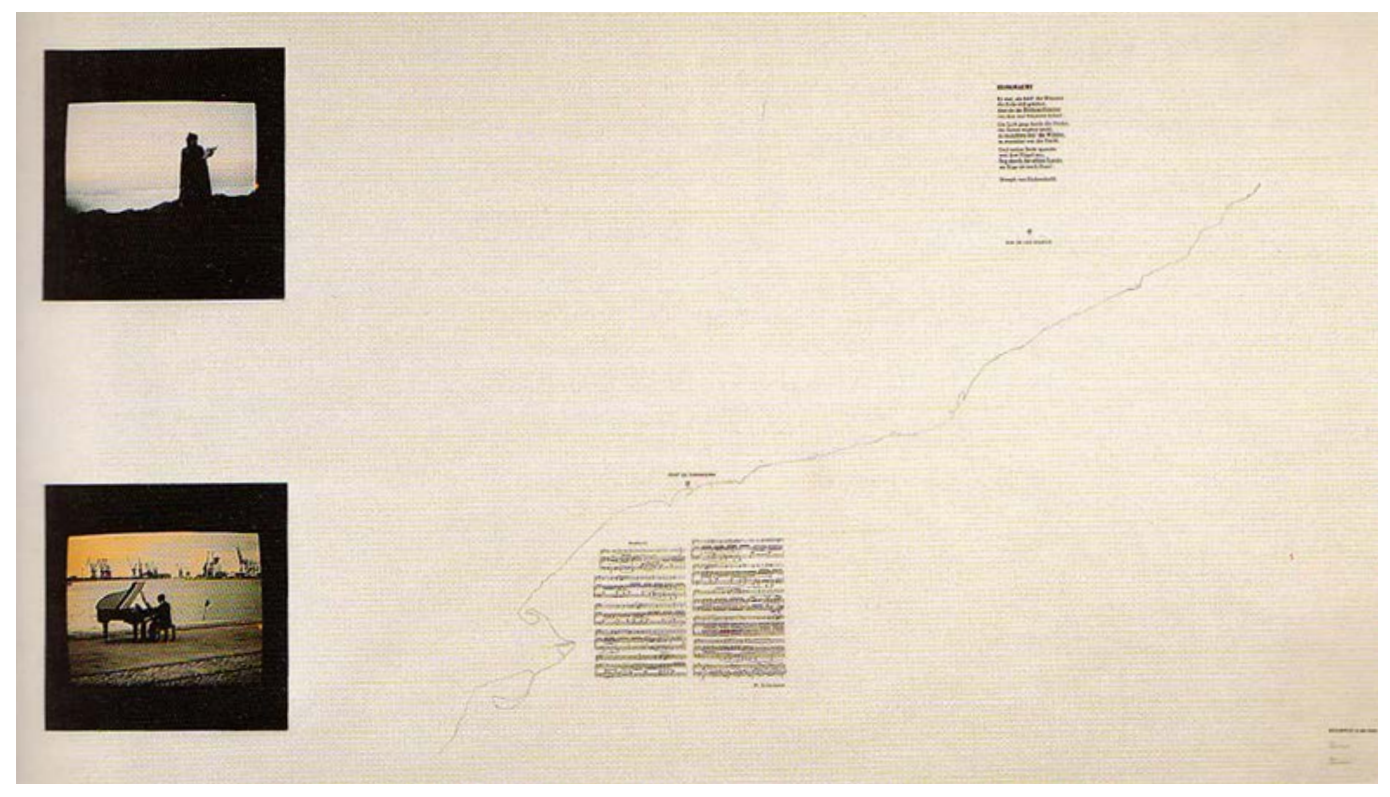

Figura 9. Descripció d'un vers.

Fuente: Partitures Plástiques (1993) Barcelona: Balmes 21

\section{PARTITURAS DIBUJADAS}

Las posibilidades expresivas del dibujo fascinan también a los compositores, que exploran la poética de este medio y lo incorporan a la partitura. En muchos casos, la experimentación con los recursos gráficos del dibujo —la exploración de la línea, la mancha, el gesto, etc.- convive con las líneas del pentagrama y los signos musicales convencionales en una síntesis de elementos gráficos codificados y no codificados. En algunos casos, las partituras son dibujos abstractos de gran calidad gráfica, como sucede en la obra del compositor japonés Toshi Ichiyanagi:

Toshi Ichiyanagi lleva el dibujo a la música y la música al dibujo, adjudicando valores temporales a la línea, y activando el espaciado y el tempo en la misma, como ya haría en la literatura Stéphane Mallarmé en Un coup de dés jamais n'abolira le hazard (1987), dando la misma importancia al espacio positivo escrito que al espacio negativo. Ese espacio entre líneas, al igual que los instrumentos no tocados en las composiciones de Ichiyanagi, desvela y revela la representación imaginada. (Hidalgo, 2014)

A Ichiyanagi pertenece también la partitura gráfica The Field (1966), realizada mediante marcas e incisiones de diferentes objetos sobre el soporte de la partitura.

Las partituras dibujadas incorporan no solo las técnicas secas sino también los medios húmedos. Uno de los más utilizados es la tinta china, aplicada en la partitura tanto a través del pincel como de otros utensilios. A través de las líneas, manchas, salpicaduras, chorreados y grafismos creados con la tinta se consiguen obras de gran expresividad. Los 
trazos creados por la tinta se inspiran a veces en la pintura oriental, como se aprecia en las partituras del compositor canadiense Randy Raine-Reusch, tales como Of Pine and Silk (2005-2007) (figura 10). Sobre esta obra, escrita para violín o cualquier otro instrumento, Raine-Reusch (1998) da las siguientes indicaciones:

Un intérprete puede ejecutar esta partitura si percibe la música al encontrarla, asegurándose de que todos los aspectos de la música estén presentes en la interpretación. Esta partitura se debe abordar de manera sinestésica más que lógica, ya que la partitura es la música más que la notación para interpretarla. Se debe considerar cada asociación, aspecto y sensación de pino y seda, incluido el pincel de hojas de pino y las sombras de los pétalos de los árboles de hojas de seda chinos. La partitura se puede realizar utilizando sonido o silencio o sin sonido ni silencio. Se puede interpretar sin notas, una nota o diez mil notas. El orden de esta partitura se determina naturalmente.

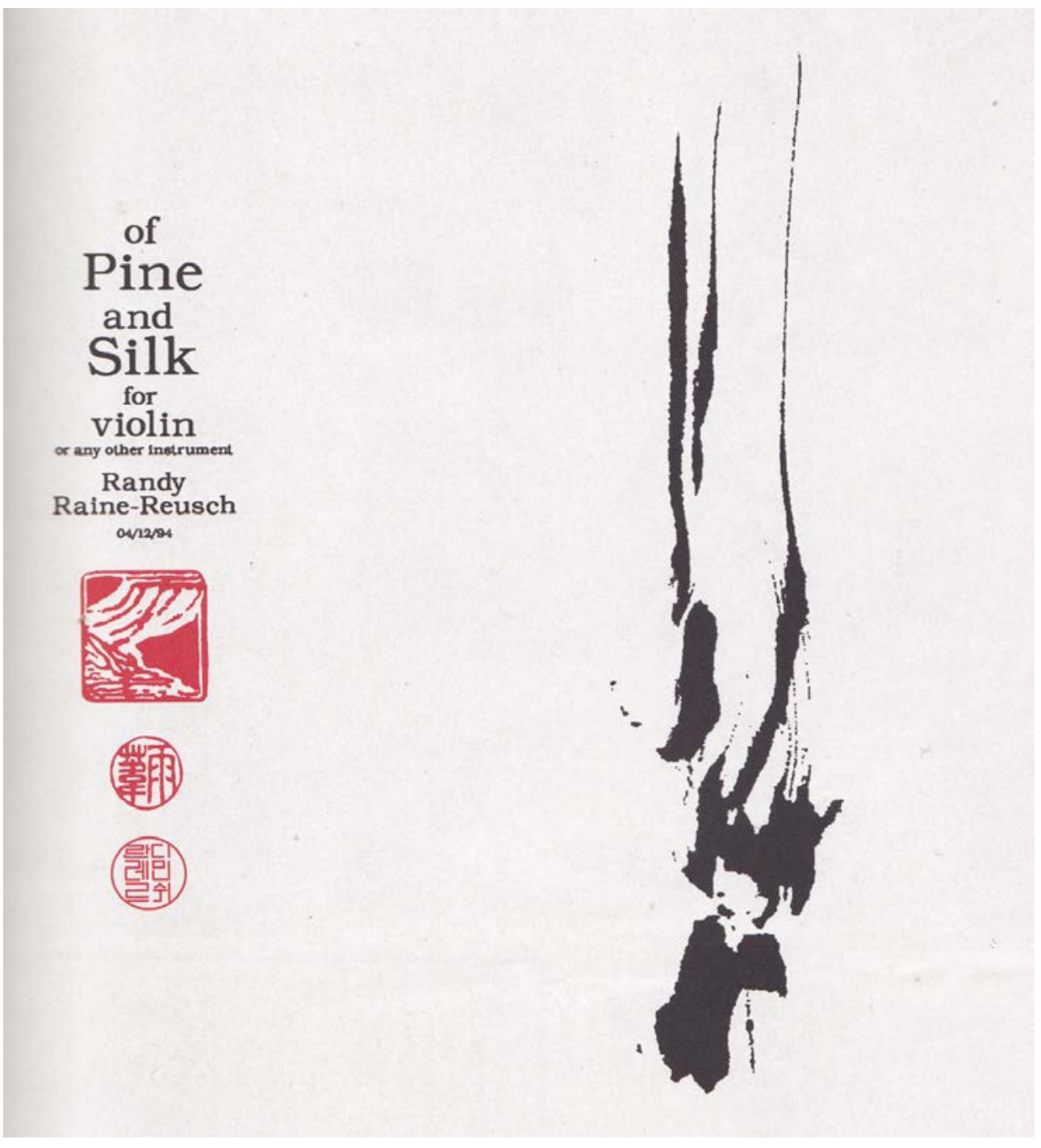

Figura 10. Of Pine and Silk (2005-2007).

(c) Copyright Randy Raine-Reusch, reproducido con el permiso del compositor Fuente: Raine-Reusch $(2009,183)$. 
Otras veces, la imaginación y creatividad de los compositores les lleva a explorar nuevos procesos operativos. Alison Knowles transgrede los límites tradicionales utilizando pieles de cebolla en el papel en su partitura Onion Skin Song o un cordón de zapato en String Shoe Song. Ambas piezas fueron realizadas incorporando estos materiales en una máquina de planos. En la actualidad, artistas y compositores emplean en muchos casos impresiones digitales, como en The Weight (1995-1997) (figura 11), partitura de Kerry John Andrews:

Mis partituras gráficas se relacionan a veces con imágenes, en su mayoría impresiones digitales. Abarcan desde las partituras tradicionales modificadas (para grandes agrupaciones, instrumentos solistas y sonidos grabados) hasta imágenes con texto (para voz) y piezas situadas en un lugar más directamente diagramático entre las anteriores (grandes agrupaciones, voces y sonidos grabados), aunque básicamente considero todas mis obras como diagramas. (Andrews 2009a, 15)

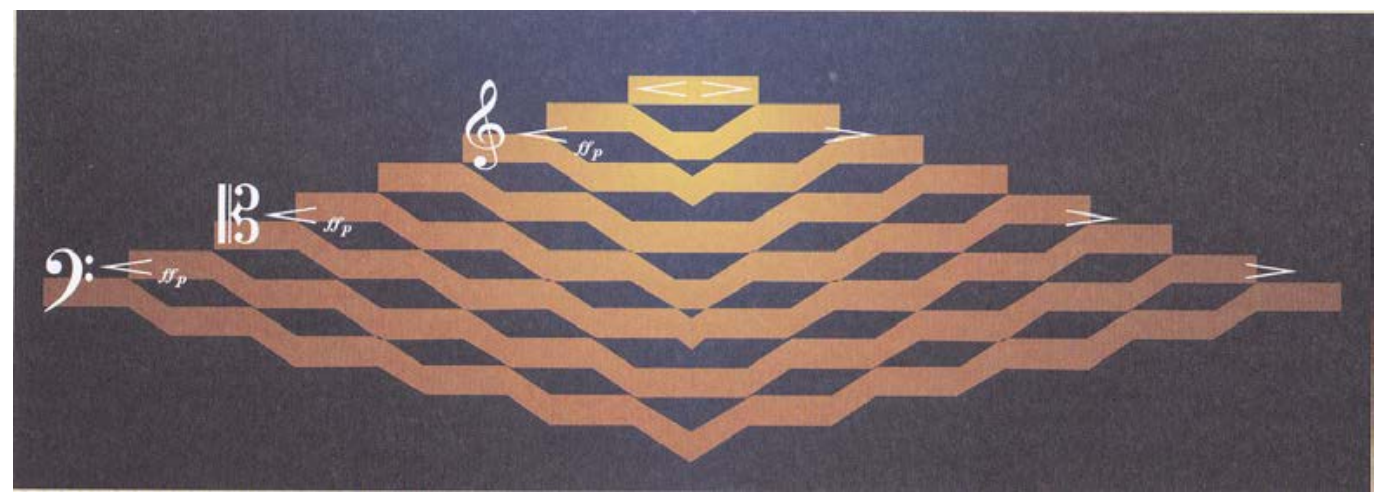

Figura 11. The Weight (1995-1997).

(c) Copyright Kerry John Andrews, reproducido con el permiso del compositor

Andrews $(2009,15)$

\section{CONCLUSIONES}

Desde su origen a mediados del siglo XX hasta nuestros días, la partitura gráfica ha incorporado distintos lenguajes visuales para la representación del sonido. Como indica Ariza,

la partitura se convierte por tanto en grafismo, intención, concepto, gesto y espacio para una composición visual, una composición plástica donde interviene la mancha y la línea, el dibujo, la geometría y el color, la numeración y la tipografía. La intervención en el soporte que representa la partitura admite cualquier tipo de acto creativo culminando con la técnica del collage. $(2008,105)$

Si el collage supone ciertamente la irrupción total de la plástica en la partitura, la experimentación en el ámbito de los lenguajes visuales va aún más allá, introduciendo nuevos y sorprendentes soportes como el vídeo, la película o el objeto tridimensional. 
Partituras tales como Stripsody (1966), de Cathy Berberian; Deutschland, ein Wintermarchen (1979), de León Schidlowsky; (...) In Effect (1986), de William Hellermann; Flight (1981), de Eugènia Balcells; Stone, Brick, Glass, Wood, Wire (1992), de Fred Frith; o Of Pine and Silk (20052007), de Randy Raine-Reusch, muestran la especial interrelación que se crea entre el lenguaje visual elegido por el compositor y las características musicales de la obra. Se alcanza en estos casos una síntesis entre elementos visuales y sonoros que resalta el carácter sinestésico de la notación musical. Se pone de manifiesto la idea de Mestres, según la cual la forma gráfica de ciertas obras es parte integrante de su propia existencia y no pueden ser imaginadas ni compuestas de otro modo (Mestres 1993, 83). La partitura gráfica investiga el aspecto visual de la representación de la idea musical, y en esta investigación sinestésica entra en juego la elección del lenguaje visual que más se adecua a las necesidades expresivas de la obra musical.

Así, vemos, por ejemplo, cómo la utilización del lenguaje del cómic en la partitura de Stripsody rescata el elemento sonoro de las historietas, la onomatopeya, para resaltar la expresividad de la interpretación vocal, la exploración de las posibilidades de la voz más allá del marco "clásico". Independizada de la escritura tradicional del sonido, la onomatopeya gráfica y literaria abre múltiples posibilidades para la experimentación y exploración sonora de la propia técnica vocal de Berberian.

En las partituras gráficas de León Schidlowsky, el uso del collage está unido a su propia concepción del proceso compositivo, basado en la síntesis de acción teatral, imagen plástica, sonido y texto literario. Su concepto de obra de arte total se plasma en la partitura mediante el lenguaje del collage.

La partitura-objeto de Hellermann actúa ofreciendo al intérprete múltiples sugerencias para la interpretación musical, instándole a desarrollar su imaginación. Las propuestas interpretativas que ofrece la partitura-objeto son variadas, pudiendo estar relacionadas, entre otros aspectos, con el tipo de instrumentos con el cual interpretar la obra, la forma musical de la pieza, la manera de combinar las notas musicales escritas, etc. La realización musical que proponen es, por tanto, abierta. Vemos, así, cómo estas "esculturas musicales" constituyen una parte central de la obra.

Cuando las partituras utilizan el vídeo como soporte y medio de expresión, a menudo, el ritmo y el tempo de las imágenes en movimiento marcan el ritmo y el tempo de la interpretación sonora. La utilización del vídeo o la película como soporte permite leer la partitura en tiempo real, quedando marcada y definida la temporalidad de la pieza. Además de estas pautas de ritmo y tempo, en algunos casos, se propone también a través de ellas la traducción de ciertos parámetros visuales a determinados elementos musicales. Esto sucede, por ejemplo, en la obra Flight, de Eugènia Balcells, en la que la posición de los pájaros en el eje vertical de la pantalla se traduce a diferentes alturas musicales, mientras que en Whitelines, de Marina Rosenfeld, la variación de amplitud y transparencia de dos bandas blancas en la pantalla se traduce en cambios en los elementos musicales, según la elección de los intérpretes.

La incorporación de la fotografía en la partitura responde a distintos tipos de relación entre sonido e imagen. En ocasiones, los compositores extraen el material musical directamente de los elementos visuales de la imagen, como sucede en la serie Stone, Brick, Glass, Word, Wire, de Fred Frith. Así, por ejemplo, la división de una fila de ventanas en dos partes sugiere al compositor la creación de un dúo instrumental, la alternancia entre luces y sombras, la de sonido y silencio, etc. Los distintos patrones visuales invitan a realizar elecciones del material musical y traducciones sonoras concretas, estableciéndose un paralelismo directo entre imagen y sonido. 
En otros casos, cuando la fotografía coexiste con la notación convencional, como sucede en algunos de los movimientos de la obra Lunar Cascade in Serial Time, de Dennis Báthory-Kitsz, imagen y realización musical comparten características comunes como la densidad, el color o la simplicidad, etc. La fotografía se utiliza también en partituras de performances musicales, complementando la escritura del proyecto performático, como vemos en la partitura de Descripció d'un vers, de Perejaume, o en Auditory, de Nadia Lichtig.

En lo que respecta a la utilización del dibujo en las partituras musicales, se dan asociaciones frecuentes entre la longitud de la línea y la duración del sonido, así como entre el grosor del trazo y la intensidad del sonido. La situación de los grafismos en el espacio da en muchos casos una idea aproximada de la altura del sonido, estableciéndose implícitamente un eje vertical para las alturas. El juego entre el negro de la tinta y el blanco del papel es frecuentemente interpretado como alternancia de sonido y silencio. Sin embargo, más allá de estas asociaciones, muchas veces el paralelismo no es tanto en cuanto a la traducción sonora de elementos gráficos concretos, sino en cuanto a la materialización de un mismo concepto que se proyecta a la vez de forma sonora y gráfica. Otras veces, como sucede en las partituras de Randy Raine-Reusch, su interpretación sonora es muy abierta, Ilegando, incluso, a realizarse de forma silenciosa, en la mente del espectador-intérprete, sin llegar a materializarse físicamente.

Hemos mencionado algunas de las relaciones sinestésicas entre imagen y sonido que se dan en partituras gráficas que hacen uso de diferentes lenguajes visuales. Estas relaciones no pretenden establecer una traducción sonora aplicable a todas las obras que hacen uso de un mismo lenguaje visual. Como Stoïanova (1973), creemos que "la escritura musical no conoce la correspondencia fija de 'signos' visuales y acontecimientos audibles. No existe un sistema de equivalencia, no hay recetas universales para la lectura-traducción de una grafía musical contemporánea" (110). Como hemos visto, el tipo de notación empleada por cada compositor, así como el lenguaje visual elegidos, están estrechamente ligados a su pensamiento musical y al contexto específico de cada obra.

Al margen de sus especificidades, todas las obras mencionadas comparten su situación entre categorías artísticas, su naturaleza plurisensorial, entre sonido y visión. En todas ellas, esta hibridación da lugar a la ampliación de recursos expresivos, a la creación de nuevos procesos visuales y sonoros, y en definitiva, al desarrollo de obras de gran riqueza conceptual y artística.

Para percibir y apreciar plenamente la relación entre el aspecto visual de las obras aquí expuestas y su traducción sonora, es ineludible su escucha. Aunque quizá esta escucha pueda ser, como propone Randy Raine-Reusch, silenciosa, en la mente del lector. 


\section{NOTAS}

1. Traducciones realizadas por Marina Buj Corral.

\section{REFERENCIAS}

Andrews, Kerry John. 2009a. "Kerry John Andrews". En Notations 21. New York: Mark Batty Publisher.

- 2009b. "The Weight." En Notations 21, Theresa Sauer. Nueva York: Mark Batty Publisher.

Ariza, Javier. 2008. Las imágenes del sonido: una lectura plurisensorial en el arte del siglo XX. Cuenca: Universidad de Castilla-La Mancha.

Balcells, Eugènia. 1981. “Flight". http://www.eugeniabalcells.com/videos/flight/content.html.

— 1995. "Film Score." http://www.eugeniabalcells.com/partituras/film/content.html.

Báthory-Kitsz, Dennis. 2007. "Lunar Cascade in Serial Time". http://maltedmedia.com/people/ bathory/music/pdf/

Berberian, Cathy. 1966. Stripsody. Leipzig: Edition Peters.

- 1966. Stripsody. Leipzig: Edition Peters.

Berenguer, Josep Manuel. 1993. "La continuidad, en el límite". En Partitures plàstiques, 84-86. Barcelona: Balmes 21.

Bosseur, Jean-Yves. 2006. Musique et arts plastiques: interactions au XXe siècle. París: Minerve.

Cox, Christopher. 2004. “Visual Rounds: On Graphic Scores". En Audio Culture, Revised Edition: Readings in Modern Music, editado por Christoph Cox y Daniel Warner, 187-188. Nueva York: Continuum.

Díaz Padilla, Ramón. 2007. El dibujo del natural: la época de la posacademia. Madrid: Akal.

Frith, Fred. 1992. "Skylight IV". En Stone, Brick, Glass, Wood, Wire (Graphic Scores 1986-96). Bolonia: I dischi di Angelica.

Fugellie Videla, Daniela. 2012. “La música gráfica de León Schidlowsky: Deutschland, ein Wintermárchen (1979) como partitura multimedial". Revista Musical Chilena 66 (218): 7-37.

Garbuglia, Andrea. 2011. Stripsody: la vocazione musicale delle strisce a fumetti. Macerata: Eum edizioni università di Macerata.

Hellerman, William. 1985. "Staff of Life II".

http://notationnotes.tumblr.com/post/6555013019/william-hellermann-staff-of-life-ii

- 2011. "Visible Music (The Score as a Sore to be Rubbed)". PAJ: A Journal of Performance and Art 33 (1): 85-92.

Hidalgo, Cristina. 2014. "Toshi Ichiyanagi: música, experimentación y recodificación del tiempo". http:// revistacultural.ecosdeasia.com/toshi-ichiyanagi-musica-experimentacion-y-recodificacion-del-tiempo/.

Hope, Cat y Lindsay Vickery. 2011. "Visualising the Score: Screening Scores in Realtime Performance". https://ro.ecu.edu.au/ecuworks2011/429/

Kandinksy, Wassily. 1977. Punto y línea sobre el plano. Barcelona: Barral.

Maur, Karin von. 1999. The Sound of Painting: Music in Modern Art. Múnich: Prestel Verlag.

Mestres Quadreny, Josep Maria. 1993. “Las nuevas grafías musicales." En Partitures plàstiques, 83-84. Barcelona: Balmes 21.

Moran, Robert. 1965. "Sketch for a Tragic One-Act Opera".

Perejaume. 1988. En Partitures plàstiques (catálogo exposición), 53. Barcelona: Balmes 21. 
Raine-Reusch, Randy. 1998. "Of Pine and Silk." http://www.asza.com/scores/r3pine.shtml.

- 2009. "Of Pine and Silk". En Notations 21. Nueva York: Mark Batty Publisher.

Raskin, Jon. 2009. “Jon Raskin". En Notations 21, 184-185. Nueva York: Mark Batty Publisher.

Reih, Ravunial. 1993. “El ojo que prolonga el oído". En Partitures plàstiques, 87-88. Barcelona: Balmes 21.

Sauer, Theresa. 2009. Notations 21. Nueva York: Mark Batty Publisher.

Schidlowsky, León. 1980. "Deutschland, ein Wintermarchen. Parte 2". http://schidlowsky.com/LeonSchidlowsky/galerien/graphics/02_1980_Deutschland_ein_Wintermaerchen_Teil_2.jpg.

Seco, Manuel, Olimpia Andrés y Gabino Ramos. 1999. Diccionario del español actual. Madrid: Aguilar.

Stoïanowa, Ivanka. 1973. “Musique, graphie, geste, musique, graphie". Musique en jeu 13: 105-114. 